\title{
Study of a measles outbreak in Granada with preventive measures applied by the courts, Spain, 2010 to 2011
}

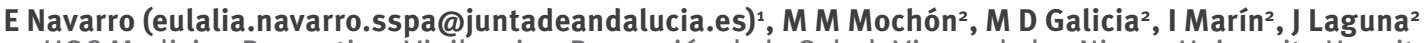

1. UGC Medicina Preventiva, Vigilancia y Promoción de la Salud, Virgen de las Nieves University Hospital, Granada, Spain

2. Epidemiology Section, Provincial Health Office, Ministry of Health, Granada, Spain

Navarro E, Mochón MM, Galicia MD, Marín I, Laguna J. Study of a measles outbreak in Granada with preventive measures applied by the courts, Spain, 2010 to 2011. Euro Surveill. 2013;18(43):pii=20612. Available online: http://www.eurosurveillance.org/ViewArticle.aspx?Articleld=20612

Measles had practically been eliminated in Granada since the systematic vaccination of children with two doses introduced in 1984. However, in 2009 the disease returned in the form of small outbreaks. This study describes the measles outbreak that occurred in Granada from October 2010 to August 2011 and the measures imposed to control it. Information was sourced from the records of the Andalusian epidemiological surveillance system. A total of 308 cases were recorded, representing an incidence rate of 33.6 cases per 100,000 inhabitants. The first wave of the epidemic took place in Granada city, with the majority of cases occurring among families who lived in the Albaycín neighbourhood and were opposed to vaccination for ideological and/or religious reasons. The initial cases were in unvaccinated children aged 1 to13 years. The outbreak later spread throughout the province. To control the outbreak, the vaccination schedule for the exposed children was brought up to date. The Regional Ministry of Health decided to take legal action in order to ensure vaccination of those in the initial nucleus of the outbreak.

\section{Introduction}

Between 2003 and 2009, substantial progress was made toward the previous World Health Organization (WHO) goal of measles elimination in the European Region by 2010 . However, since late 2009, measles virus transmission has increased, and outbreaks have become widespread. In 2011, measles outbreaks were reported in 36 of 53 WHO European Region member states. Overall, the primary reason for the increased transmission and outbreaks of measles in the WHO European Region is failure to vaccinate susceptible populations [1]. The European Surveillance System (TESSy) detected a total of 30,567 cases of measles throughout the European Union (EU) and European Economic Area (EEA) [2].

The mean coverage of vaccination against measles increased from 1990 to 2008 in the WHO European Region, reaching an estimated average measles vaccine coverage of $95 \%$ or above in 30 of the Region's 53
Member States [3]. The appearance of outbreaks, particularly in Western Europe and more recently in Spain, has been related to the existence of pockets of susceptible people. These can often be divided into two main groups: a growing number of susceptible children of parents who distrust vaccinations, and those belonging to disadvantaged groups [3-6]. In Spain, 45 measles outbreaks were recorded across 17 autonomous regions in 2011, reaching a total of 3,647 cases [7]. The majority of these occurred in Andalusia $(n=2,113$ cases), Madrid $(n=601)$ and Catalonia $(n=315)[7,8]$.

In Andalusia, childhood vaccination against measles began in 1984. The measles-mumps-rubella (MMR) vaccine is administered at the age of 15 months. Since 1990 a second dose has been administered at the age of 11 years. In 2004, the age for the second dose has been changed to three years. Before 1984, between 8,000 and 98,000 cases of measles had been recorded annually, representing an incidence rate of 130 to 1,500 cases per 100,000 inhabitants per year. After the introduction of vaccines, the incidence rate fell dramatically, with just three cases per 100,000 inhabitants per year recorded in 2002 and 2004. Two small outbreaks were recorded in 2003 (Almeria, 185 cases) and 2008 (Algeciras, 247 cases) [9]. In 2010 an epidemiological alert protocol for measles was introduced in Andalusia, which set out the steps to take in the event of an outbreak or sporadic measles cases recorded [10].

In Granada Province, the incidence rate for measles had continued to fall since the two major epidemics in 1983 and 1985, with no cases at all recorded in 2001 and 2002. This trend was interrupted in 2009 with an outbreak of 22 cases among children in the south of the province, most of whom had not been vaccinated for ideological reasons [11,12]. In October 2010, a measles outbreak began in the Albaycín neighbourhood of the city of Granada and later spread across the rest of the city and throughout the province. Initial data for this outbreak have been published on previous occasions $[5,6]$. 
TABLE

Measles outbreak cases with prior contact to other confirmed measles cases, Granada Province, 2010-11 $(n=130)$

\begin{tabular}{|l|c|c|c|}
\hline Prior contact & Residents & Professionals & Total \\
\hline Attendance of family event & 6 & 0 & 6 \\
\hline School & 16 & 0 & 16 \\
\hline Household contact & 71 & 0 & 71 \\
\hline Health centre & 20 & 11 & 31 \\
\hline Workplace & 0 & 1 & 1 \\
\hline Case in another country & 5 & 0 & 5 \\
\hline Total & $\mathbf{1 1 8}$ & $\mathbf{1 2}$ & $\mathbf{1 3 0}$ \\
\hline
\end{tabular}

The objective of this study was to describe and analyse the characteristics of the outbreak recorded in Granada Province, and the measures taken to control it.

\section{Methods}

A descriptive analysis was done of the measles cases recorded in Granada during the epidemic period, on the basis of the variables of patient, location and time. Cases were considered confirmed i) when there was a laboratory diagnosis of infection or ii) when the rash had first appeared seven to 18 days earlier and they had an epidemiological link to a laboratory confirmed case. Laboratory confirmation was carried out by serology, (detection of specific IgM) and/or PCR or by isolating the virus in a throat culture or in urine. In accordance with the existing protocol, cases were considered clinically compatible when they met the clinical criteria but there was no laboratory confirmation or link with a confirmed case [10].

Outbreak data were obtained through the Andalusian Epidemiological Surveillance System's (Sistema de Vigilancia Epidemiológica de Andalucía, SVEA) alert network and processed using Microsoft Excel and Epi Info version 3.4.3. The univariate analysis included the calculation of means and medians for quantitative variables, and frequencies and percentages for qualitative variables. Incidence rates per 100,000 and by age group were also calculated.

\section{Results}

\section{Outbreak description}

On 25 October 2010, two cases of measles were recorded in unvaccinated children from the Albaycín neighbourhood of Granada. From that date until 27 August 2011 (week 34), considered to be the epidemic period, 372 suspected cases of measles were recorded throughout Granada Province: 287 of these were confirmed and 21 were compatible cases, and 64 were rejected. These 308 recorded measles cases represented an incidence rate of 33.6 cases per 100,000 inhabitants over the period of the outbreak.
In the first wave of the outbreak between 10 and 12 October 2010, there were six confirmed cases, all involving children of between one and 13 years-old who belonged to a religious community in Albaycín and had attended a family event that took place between 15 and 16 days before their onset of symptoms. A second and third wave of new cases were identified, with 10 and 16 cases, respectively, who had known epidemiological links with earlier cases within the family, neighbourhood, at school or at the hospital (Table).

With the progression of the epidemic, 148 cases occurred in the city of Granada and municipalities in the surrounding metropolitan area for whom there was no known contact with earlier cases. Finally, in late spring and early summer 2011, the outbreak reached the south of the province, where the last cases were recorded on 27 August 2011.

In 31 cases (10\% of the total), measles infection was acquired at a healthcare centre. Eleven of the registered cases were healthcare workers; nine of them were between 25 and 36 years-old and two were older than 45 years. Six were doctors in training. There is no evidence of secondary cases as a result of transmission via these healthcare workers.

The average age of cases was 15 years (range: 25 days to 48 years). The measles incidence was highest in children under the age of 16 months $(679.5$ cases per 100,000 inhabitants), followed by children aged between 16 months and four years (106.6 cases per 100,000 inhabitants). Among the total number of cases, 80 (26\%) were younger than 16 months and 134 (44\%) were between 15 and 34 years-old. There were no cases older than 48 years (Figure 1 ).

The age distribution among the initial cases, which occurred in the Albaycín neighbourhood, was different from the later cases in the outbreak, with a predominance of cases (21 of 26 cases) in children between 16 months and 14 years-old (Figure 1).

The sex ratio (male/female) was 1.18 for the entire outbreak. The hospitalisation rate was $23 \%$ (71 cases), lowest for the age group from five to 14 years $(6.2 \%)$ and highest for the age group 34 years and above $(47.8 \%)$. No deaths were recorded during the outbreak period.

\section{Laboratory confirmation}

Of the 287 confirmed cases, 254 (89\%) were confirmed in the laboratory: 56 cases $(22 \%)$ by PCR alone, 80 (32\%) by serology (positive IgM) alone, and 118 cases (46\%) with both methods. The genetic sequence of 22 samples that were sent to the National Microbiology Centre at the Carlos III Healthcare Research Institute, WHO reference laboratory for measles in Madrid, Spain, corresponded to the B3 genotype. These 22 samples had been taken at different times and places during the outbreak. 


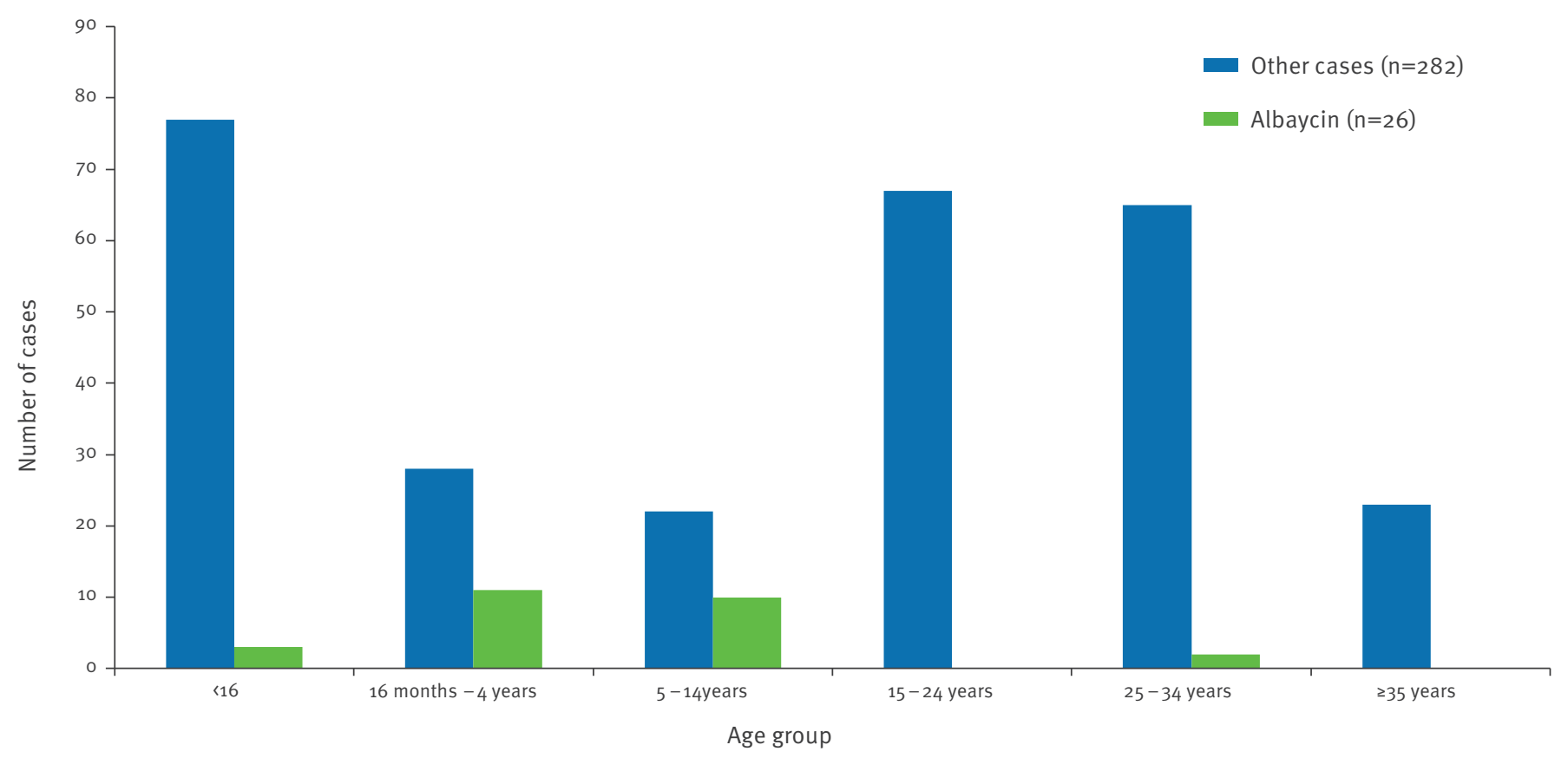

\section{Vaccination coverage}

In $89 \%$ of the 287 confirmed cases, the patient had not received any dose of MMR vaccine. Moreover, $81 \%$ of the 138 patients aged between 16 months and 24 years (the age range in which a high level of vaccination coverage is to be expected) had not received any dose of the vaccine. One dose of MMR had been given to 31 cases, for 10 of them documented. No case had received the second MMR dose.

\section{Control measures}

From the moment the first case was declared, the measures given in the alert protocol for measles namely, isolating the cases and monitoring contact were adopted in order to prevent new cases from developing (Figure2).

The initial actions were aimed at the affected five institutions: two childcare centres (children aged $0-3$ years) with one and two cases, two primary schools (children aged 3-12 years) in the neighbourhood with one and 10 cases, and one secondary school (children aged 12-16 years) in the city centre with one case. In four of the five schools, the parents were cooperative in terms of checking and keeping up to date with the vaccination schedule for the children. However, in the primary school in which the first cases had appeared, the vaccination coverage was low (63\% of the ca. 200 pupils). Meetings with the parents were organised and informative letters were sent to the homes of all children in schools and childcare centres in Albaycín, requesting that the parents present the children's vaccination records and/or give written consent for their children to be vaccinated. Some parents refused the proposed vaccination on religious or ideological grounds (antivaccination beliefs based on naturopathy or alternative medicine).

On 10 November 2010, burofaxes (a reliable means of communication in Spain) were sent to the parents of 79 students demanding the vaccination of the child or the presentation of the vaccination card in the school. In response, 44 children were either vaccinated or presented their card (Figure 2).

As the parents of 35 pupils at the primary school either failed to respond or rejected the vaccination, the Regional Ministry of Health requested authorisation from Granada Contentious-Administrative Court on 18 November 2010 to adopt the measures it considered urgent and necessary for public health, in accordance with the Special Measures for Matters of Public Health Act (Organic Law 3/1986 of 14 April 1986). The Ministry requested the forced vaccination of those children whose parents had expressly refused it or had failed to submit the child's vaccination record. Six days later, the presiding judge agreed to "authorise the forced vaccination of the 35 children named in the list provided by the Provincial Office. The vaccination may be performed at the primary school, at the hospital or in the children's homes, and is to be performed by specialist healthcare professionals".

The parents of said children were informed of this decision immediately. As a result of the decision, four children were vaccinated and a further 21 provided 


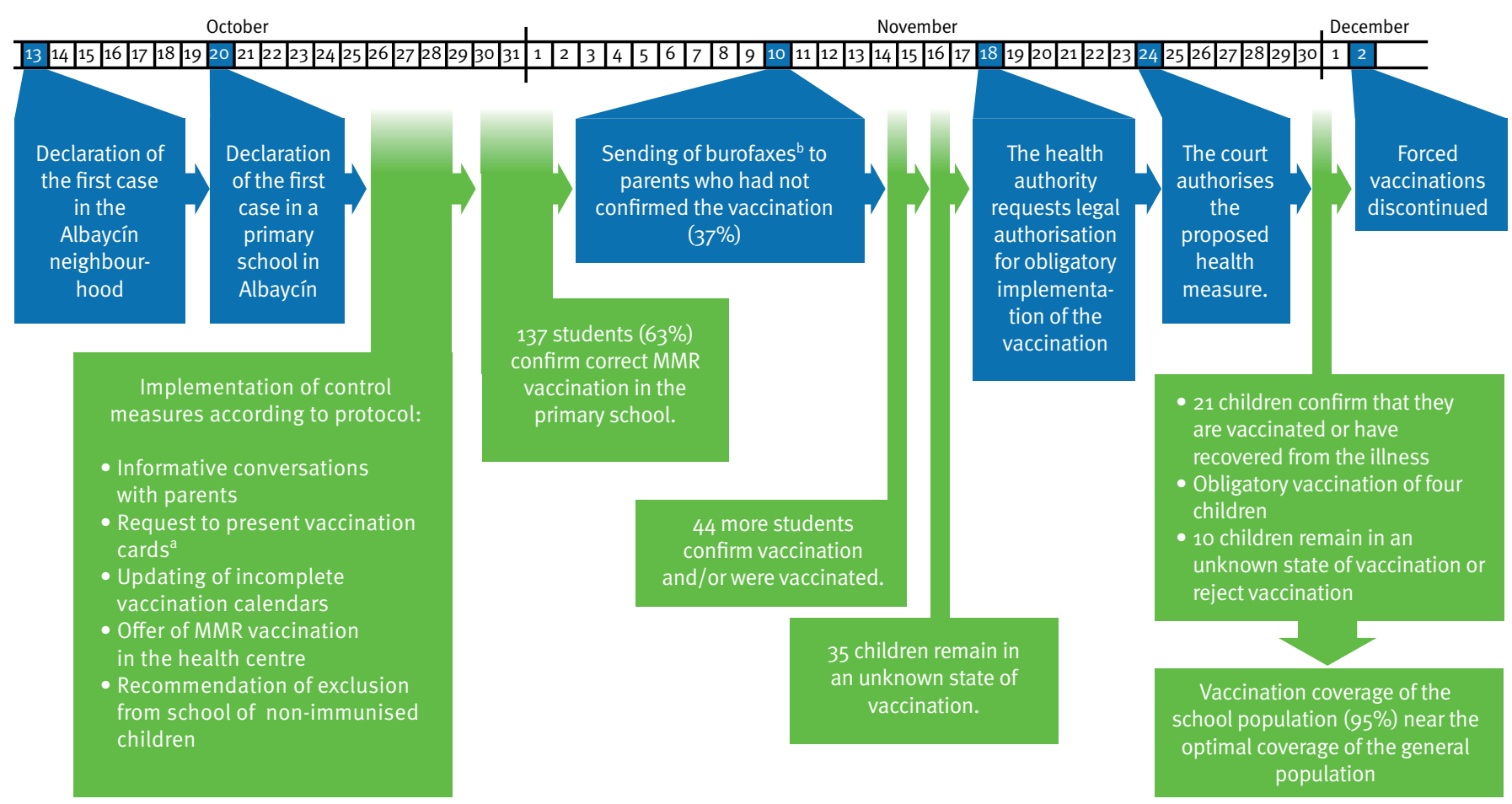

MMR: measles-mumps-rubella.

a The request for vaccination cards was put out in different meetings and by letter.

b Burofax: a means of notification that confirms the content of the communication and serves as evidence in court and public administrations.

evidence that they had already been vaccinated or had already had measles (four of them had contracted measles during the ongoing epidemic). Some families rejected the vaccination.

On 2 December 2010, the provincial office of the Regional Ministry of Health submitted a written report to the court stating that it believed the situation of special risk detected at the primary school to have passed, as the proportion of pupils with immunity, whether through vaccination or contracted disease, exceeded $95 \%$, which was considered sufficient to control the outbreak and render the forced vaccination of the remaining ten children unnecessary. The presiding judge responded that it was up to the Ministry to decide whether or not to carry out the authorised measures.

On 22 July 2013, the High Court of Justice of Andalusia refused the appeal lodged by two parents against the forced vaccination of their children.

Another measure was adopted during November 2010, when new cases of measles occurred, many of them in infants outside the Albaycín neighbourhood: the
Regional Ministry lowered the age for the first dose of the MMR vaccine and authorised its administration to all children aged 12 months in the city of Granada and to those in other municipalities where one or more cases had been reported, for the period while the risk remained. This measure was modified two weeks later after measles cases were recorded in children under the age of 12 months: the Ministry decided to lower the vaccination age further to include all infants aged six months and older in the city of Granada and in those municipalities in which one or more cases had been recorded.

At the beginning of the outbreak, two cases were recorded who had contracted the infection at the paediatric accident and emergency department at a hospital in the city of Granada. Consequently, and in accordance with the alert protocol, the decision was made to isolate suspected cases at the accident and emergency department and to distribute information concerning the outbreak to the medical services that could potentially be affected. Serological tests and vaccination of healthcare workers under the age of 40 years was 
recommended. A few tests were negative and there is only a record of four of those workers being vaccinated.

\section{Discussion}

Measles incidence rates as high as those reached in Granada Province during this outbreak have not been recorded for more than 20 years. The median age of the cases diagnosed at the start of the outbreak in 2010 was two years, which was much younger than the median age (19 years) of the cases diagnosed in 2011. The first waves of the epidemic involved many unvaccinated children living in the Albaycín neighbourhood. We think the main reason was that their parents were opposed to vaccination $[6,12,13]$. The higher age of cases in 2011 is suggestive of a historical pocket of susceptible adults (born before the start of the vaccination regime in 1984 but who did not contract the disease because vaccination rapidly interrupted the circulation of the virus). This phenomenon was also observed in other outbreaks occurring in 2011 in Spain and other European countries such as France which reported the largest number of cases (approximately 14,000). The median age of cases in those outbreaks were, respectively, 18 years (Spain) and 16 years (France) [2].

Due to the effectiveness of the vaccine, the majority of cases in the Granada outbreak occurred in an unvaccinated population. These were not only children under the age of 15 months not eligible for the first dose of the vaccine, but also a larger than anticipated unvaccinated population of susceptible adults born before 1984 and people who had not been vaccinated on ideological and/or religious grounds or as a result of belonging to an underserved population [12].

\section{Coercive measures can be necessary to} control outbreaks in certain situations

[12-14]. At the start of this outbreak, there was a risk of the disease spreading to the rest of the city because a significant proportion of parents in the Albaycín neighbourhood were not willing to support the catch-up vaccinations. This led the Regional Ministry of Health to adopt a highly unusual measure: it requested the Contentious-Administrative Court to authorise the forced vaccination of 35 children. The court's decision in a situation of conflict between the right to choose not to be vaccinated and the protection of the health of the collective was a significant boost to the control activities: it changed the attitudes of some of the parents, prompting them to have their children vaccinated, and made it possible to determine that many of the other children were not susceptible to measles.

A precedent of a coercive measure adopted by the health services and supported by the legal authorities had occurred in Berlin in 2010, during an outbreak of measles at a private school (a 'Waldorfschule') where many pupils had not been vaccinated as a result of their parents' anti-vaccination stance. The public health authorities decided to adopt the legal measures foreseen in the legislation, such as withdrawing from school those pupils who were unvaccinated and who had not already contracted (and recovered from) measles. The parents lodged an appeal against this decision with Berlin Administrative Court; however, the judge found in favour of the utility and legality of the measure [15].

Exclusion from school of children that were unvaccinated and/or not immune was recommended in the Albaycín school, but never imposed by the education or legal authorities. However, faced with the inefficiency of this recommendation, the health authority later decided to appeal to the court to apply forced vaccination as a measure of control. According to the literature consulted, this measure had not previously been taken in Spain or in other countries in Europe.

A significant proportion of the exposed healthcare workers, such as training medical specialists and other young professionals, were part of the group considered susceptible on account of their age (25 to 35 years-old). Given that on this occasion, the efforts made to vaccinate health workers were not sufficient to prevent the disease, it would be important to ensure the vaccination schedule for these professionals is up to date when they start work $[11,16,17]$. Contact with other patients in the accident and emergency departments of the hospitals involved led to the infection of at least 20 people who had visited the hospital for other reasons. This highlights the importance of reinforcing the early diagnostic isolation and treatment measures for suspected measles cases during an outbreak.

The most frequently recorded genotype in the latest outbreaks in Spain (Madrid, Seville and Valencia) and across Europe was the D4 genotype [18]. The B3 genotype isolated in the Granada outbreak is less common in Spain and the rest of Europe and could have been imported from Africa [19].

In conclusion, the measles outbreak recorded in Granada during 2010-11 was notable for the low vaccination coverage among certain sections of the population, the role played by nosocomial transmission of the disease, and the use of court-approved coercive measures to gain control over the outbreak. 


\section{Acknowledgements}

We are grateful for the efforts of all those who helped control the outbreak and generated the information used in this study, especially the professionals working in the Primary Healthcare Districts, the various departments of Preventive Medicine in the region's hospitals and the laboratory at the Microbiology Department in Virgen de las Nieves University Hospital, where the virus was examined.

\section{Conflict of interest}

None declared.

\section{Authors' contributions}

All authors contributed to the writing of the manuscript and agree with the results and conclusions.

\section{References}

1. Centre for Disease Control Prevention (CDC). Increased Transmission and Outbreaks of Measles - European Region, 2011. MMWR Morb Mortal Wkly Rep. 60(47):1605-10. PMid:22129994.\#

2. European Monthly Measles Monitoring (EMMO). Surveillance Report Issue 8. Stockholm: European Centre for Disease Prevention and Control; 21 Feb 2012. Available from: http:// ecdc.europa.eu/en/publications/Publications/SUR_EMMO European-monthly-measles-monitoring-February-2012.pdf

3. World Health Organization (WHO) Regional Committee for Europe. Renewed commitment to measles and rubella elimination and prevention of congenital rubella syndrome in the WHO European Region by 2015. Copenhagen: WHO Regional Office for Europe; 23 Jul 2010. Report EUR/RC60/15. Available from: www.euro.who.int/_data/assets/pdf file/oo08/119546/RC60_edoc15.pdf

4. Tagarro García A, Jiménez Bueno S, Herreros Fernández ML, et al. Brote de 22 casos de sarampión autóctono en la zona norte de Madrid. [Outbreak of measles in the population of Spanish origin in North Madrid]. An Pediatr (Barc). 2012;76(6):350-4. Spanish.

http://dx.doi.org/10.1016/j.anpedi.2011.11.017

PMid:22265376.

5. López Hernández B, Laguna Sorinas J, Marín Rodríguez I, Gallardo García V, Pérez Morilla E, Mayoral Cortés JM. Spotlight on Measles 2010: An Ongoing Outbreak of Measles in an Unvaccinated Population in Granada, Spain, October to November 2010. Euro Surveill. 2010;15(50): pii=19746. Available from: http://www.eurosurveillance.org/ViewArticle. aspx?Articleld=19746. PMid:21172172.

6. Martínez Romero M, Martínez Diz S, García Iglesias F. ¿Por qué los padres no vacunan a sus hijos? Reflexiones tras un brote de sarampión en un barrio de Granada. [Why don't parents vaccinate their children? Reflections on a measles outbreak in a neighbourhood of Granada). An Pediatr (Barc). 2011;75(3):209-10. Spanish. http://dx.doi.org/10.1016/j. anpedi.2011.04.002. PMid:21676666.

7. National Epidemiology Centre, Carlos III Healthcare Research Institute. Comentario epidemiológico de las enfermedades de declaración obligatoria y sistema de información microbiológica. Espa-a. A-o 2011. [Epidemiological review of reportable diseases and microbiological information system. Spain. 2011). Weekly Epidemiological Bulletin. 2012; 20(14):124-34. Spanish. Available from: http://revista.isciii.es/ index.php/bes/article/viewArticle/750

8. National Epidemiology Centre, Carlos III Healthcare Research Institute. Casos notificados de sarampión en el a-o 2011. [Measles cases reported in 2011]. Weekly Epidemiological Bulletin. 2012;20(6):56-57. Spanish. Available from: http:// revista.isciii.es/index.php/bes/article/viewArticle/705/750

9. Nieto-Vera J, Masa-Calles J, Dávila J, Molina-Font J, Jiménez M, Gallardo-García V, et al. An outbreak of measles in Algeciras, Spain, 2008 - a preliminary report. Euro Surveill. 2008;13(20):pii=18872. Available from: http://www. eurosurveillance.org/ViewArticle.aspx?Articleld=18872. PMid:18761974

10. Protocolo de alerta epidemiológica por sarampión. [Protocol of an epidemiological alert for measles]. Sevilla: Consejería de Salud, Junta de Andalucía [Andalusian Regional Ministry of Health]. [Accessed: 26 Jun 2012]. Spanish. Available from: http://www juntadeandalucia.es/salud/export/sites/csalud/ galerias/documentos/p_4_p_1_vigilancia_de_la_salud/ Protocolos_actuacion/sarampion.pdf

11. Informe anual del plan de eliminación del sarampión, rubéola y síndrome de rubéola congénita en Espa-a, 2010. [Annual report on the plan for the elimination of measles, rubella and congenital rubella syndrome in Spain, 2010]. Madrid: National Centre of Epidemiology, Institute of Health Carlos III; Aug 2011. Spanish. Available from: http://www.isciii.es/ISCIII/es/contenidos/fd-servicioscientifico-tecnicos/fd-vigilancias-alertas/fd-enfermedades/ fd-enfermedades-prevenibles-vacunacion/Informe-Anual-PlanEliminacion-del-Sarampion-Rubeola-y-Sindrome-de-RubeolaCongenita-Espana-2010.pdf

12. Muscat M. Who gets measles in Europe? J Infect Dis. 2011;204(Suppl 1): S353-65. http://dx.doi.org/10.1093/infdis/ jiro67. PMid:21666185.

13. Schmid D, Holzmann H, Abele S, Kasper S, König S, Meusburger S, et al. An ongoing multi-state outbreak of measles linked to non-immune anthroposophic communities in Austria, Germany, and Norway, March-April 2008. Euro Surveill. 2008;13(16):pii=18838. Available from: http://www. eurosurveillance.org/ViewArticle.aspx?Articleld $=18838$

14. Simon-Lorda P. 25 ideas clave sobre ética y vacunación del sarampión. [25 key ideas about ethics and measles vaccination]. [Accessed: 2012-06-26]. Spanish. Available from: http://es.scribd.com/doc/43804784/25-ideas-claves-sobreetica-y-vacunacion-del-sarampion

15. Bätzing-Feigenbaum J, Pruckner U, Beyer A et al. Spotlight on measles 2010: Preliminary report of an ongoing measles outbreak in a subpopulation with low vaccination coverage in Berlin, Germany, January-March 2010. Euro Surveill. 2010;15(13): pii=19527. Available from: http://www. eurosurveillance.org/ViewArticle.aspx?Articleld=19527. PMid:20394713.

16. Guaita Calatrava R, Giner Ferrando E, Bayo Gimeno J, Yuste Muoz L, Saiz Sánchez C, Ortí Lucas RM, et al. Brote nosocomial de sarampión. [An outbreak of nosocomial measles]. Weekly Epidemiological Bulletin. 2011;19(16):220-7. Spanish. Available from: http://revista.isciii.es/index.php/bes/article/ view/354/382

17. Delaporte E, Jeannot E, Sudre P, Wyler Lazarevic CA, Richard JL, Chastonay P. Measles in Geneva between 2003 and 2010: persistence of measles outbreaks despite high immunisation coverage. Euro Surveill. 2011;16(39):pii=19980. Available from: http://www.eurosurveillance.org/ViewArticle. aspx?Articleld $=19980$

18. Vainio K, Steen TW, Arnesen TM, Rønning K, Ånestad G, Dudman S. Measles virus genotyping an important tool in measles outbreak investigation in Norway, 2011. Euro Surveill. 2012;17(50):pii=20340. Available from: http://www. eurosurveillance.org/ViewArticle.aspx?Articleld=20340. PMid:23241234.

19. Riddell MA, Rota JS, Rota PA. Review of the temporal and geographical distribution of measles virus genotypes in the prevaccine and postvaccine eras. Virol J. 2005;2:87. http://dx.doi.org/10.1186/1743-422X-2-87. PMid:16303052. PMCid:PMC1318492. 